\title{
ANALISIS PELAYANAN AKTA KELAHIRAN ONLINE DI KELURAHAN NAMBOJAYA KECAMATAN KARAWACI KOTA TANGERANG PROVINSI BANTEN
}

\author{
Oleh \\ Dinda Kemala Puspadiwati ${ }^{1}$, \\ Djohermansyah Djohan ${ }^{2}$, M. Irwan Tahir ${ }^{3}$ \\ 1) Pemerintah Daerah Kota Tangerang \\ Program Magister Terapan Studi Pemerintahan Daerah Institut Pemerintahan Dalam Negeri \\ deendaakmal@gmail.com \\ 2,3) Institut Pemerintahan Dalam Negeri
}

\begin{abstract}
"ANALYSIS OF ONLINE BIRTH CERTIFICATE SERVICES IN NAMBOJAYA SUBDISTRICT, KARAWACI SUBDISTRICT, TANGERANG CITY, BANTEN PROVINCE"
\end{abstract}

$T$

e phenomenon that becomes the object of research is the implementation of policies in online

birth certificate services. The research objectives were (1) to analyze the implementation of the online birth certificate service policy in Tangerang City, especially in Nambojaya Village, Karawaci District, Tangerang City; analyzing the obstacles faced in improving the innovation of online birth certificate services in Nambojaya Village, Karawaci District, Tangerang City.

The research method used isdescriptive qualitative method which aims touncover and discuss implementation of online birth certificate service policies. Data collection was carried out by literature study and direct interviews with research informants. Determination The sample used the snow ball technique, namely by obtaining as many as five research informants.

Based on the discussion of the research results, the following conclusions were obtained, namely: The political environment still needs evaluation and improvement of ASN capabilities; Leadership lack of guidance to ASNs; Planning that is considered to be in accordance with the applicable legal umbrella, namely Mayor Regulation number 96 of 2016 concerning the master plan of information and communication technology for Tangerang City 2016-2018 and Mayor Regulation Number 2 of 2016 concerning the use of information and communication technology; Stakeholders in influencing the implementation of policies have not yet reached the achievement targets that have been set; Transparency/Visibility of supervision created is still weak; Budget is still an obstacle in itself for urban villages to be able to overcome problems that arise in online-based birth certificate services; Technology users that are still not optimized; The State Civil Apparatus has not fully carried out the Innovation.

Keywords: policy implementation, innovation, online.

\section{ABSTRAK}

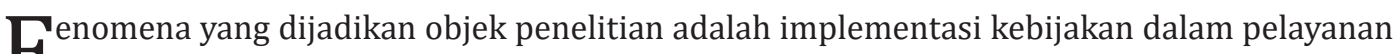
Fakta kelahiran online. Tujuan penelitian adalah (1) menganalisis implementasi kebijakan 
pelayanan akta kelahiran online di Kota Tangerang khususnya di Kelurahan Nambojaya Kecamatan Karawaci Kota Tangerang; menganalisis kendala-kendala yang dihadapi dalam peningkatan Inovasi pelayanan akta kelahiran online di Kelurahan Nambojaya Kecamatan Karawaci Kota Tangerang.

Metode penelitian yang digunakan adalah metode kualitatif deksriptif yang bertujuan untuk mengungkap dan membahas implementasi kebijakan pelayanan akta kelahiran secara online. Pengumpulan data dilakukan dengan studi kepustakaan dan wawancara langsung kepada informan penelitian. Penentuan sampel digunakan snow ball technique, yaitu dengan memperoleh sebanyak lima informan penelitian.

Berdasarkan pembahasan hasil penelitian diperoleh simpulan, yaitu Political environment masih perlu adanya evaluasi dan peningkatan kemampuan ASN; Leadership kurangnya pembinaan kepada ASN; Planning yang dinilai sudah sesuai dengan payung hukum yang berlaku, yakni Peraturan Wali Kota No. 96 Tahun 2016 tentang Rencana Induk Teknologi Informasi dan Komunikasi Kota Tangerang tahun 2016-2018 dan Peraturan Wali Kota No. 2 Tahun 2016 tentang Pemanfaatan Teknologi Informasi dan Komunikas; Stakeholder dalam memengaruhi implementasi kebijakan masih belum mencapai target pencapaian yang telah ditetapkan; Transparency/Visibility pengawasan yang tercipta masih lemah; Budget masih menjadi kendala tersendiri bagi kelurahan untuk dapat mengatasi permasalahan yang timbul pada Pelayanan Akta Kelahiran berbasis online; Pemanfaat teknologi yang masih kurang dioptimalkan; Aparatur Sipil Negara belum sepenuhnya melakukan Innovation.

Kata kunci: implementasi kebijakan, inovasi, online.

\section{PENDAHULUAN}

Cebagai salah satu negara yang Omenerapkan sistem otonomi daerah dalam pelaksanaan pemerintahannya, Indonesia memberikan kewenangan kepada daerahnya untuk mengatur dan mengurus sendiri daerahnya sesuai dengan peraturan perundang-undangan. Dalam otonomi daerah penyelenggaraan pemerintahannya didasarkan atas tiga asas, yakni desentralisasi, dekonsentrasi, dan tugas pembantuan. Tugas pembantuan merupakan penugasan dari pemerintah pusat kepada daerah otonom untuk melaksanakan sebagian urusan pemerintahan yang menjadi kewenangan pemerintahan pusat atau dari pemerintah daerah provinsi kepada daerah kabupaten/ kota untuk melaksanakan sebagian urusan pemerintahan yang menjadi kewenangan daerah provinsi. ${ }^{1}$

Urusan pemerintahan itu sendiri merupakan kekuasaan pemerintahan yang menjadi kewenangan presiden yang pelaksanaannya dilakukan oleh Kementerian negara dan penyelenggara pemerintah daerah untuk melindungi, melayani, memberdayakan, dan menyejahterakan masyarakat. Menurut Undang-Undang No. 23 Tahun 2014 tentang Pemerintahan Daerah Pasal 9 ayat (1) urusan pemerintah terbagi atas tiga urusan, yakni urusan pemerintahan absolut; urusan pemerintahan konkuren; dan urusan pemerintahan umum. ${ }^{2}$

Urusan pemerintahan konkuren merupakan urusan pemerintahan yang dibagi antara pemerintah pusat, daerah provinsi dan daerah kabupaten/kota, yang terdiri atas urusan wajib dan urusan pilihan. Selanjutnya terdapat dua bentuk urusan pemerintahan wajib, yakni wajib yang berkaitan dengan pelayanan dasar dan wajib yang tidak berkaitan dengan pelayanan dasar. Administrasi kependudukan dan pencatatan sipil merupakan salah satu urusan wajib yang tidak berkaitan dengan pelayanan dasar yang menjadi tanggung jawab daerah otonom. Administrasi kependudukan menurut Undang-Undang No. 24 Tahun 
2013 tentang Administrasi Kependudukan adalah rangkaian kegiatan penataan dan penertiban dalam penerbitan dokumen dan data kependudukan melalui pendaftaran penduduk, pencatatan sipil, pengelolaan informasi administrasi kependudukan serta pendayagunaan hasilnya untuk pelayanan publik dan pembangunan sektor lain. ${ }^{3}$

Data kependudukan memiliki nilai strategi bagi penyelenggara pemerintahan, pembangunan dan pelayanan kepada masyarakat. Hal tersebut menunjukkan bahwa kegiatan administrasi kependudukan menjadi masalah yang paling urgent, yang harus ditangani dengan baik dan serius oleh pemerintah. Mulai dari penunjukan instansi khusus yang akan mengelola informasi kependudukan hingga pengoordinasian data yang jelas dan berkesinambungan. Perolehan data dari proses tersebut akan menjamin stabilitas pelayanan kepada masyarakat di bidang kependudukan karena kemudian penetapan kebijakan oleh pemerintah salah satunya akan didasarkan pada informasi data kependudukan tersebut.

Pendaftaran penduduk dan pencatatan sipil merupakan hak serta kewajiban bagi setiap warga negara. Hak dalam memperoleh perlindungan dan pengakuan secara hukum serta memperoleh pelayanan dari negara, selanjutnya juga merupakan suatu kewajiban di mana setiap warga negara berkewajiban untuk melakukan pendaftaran penduduk maupun melaporkan setiap peristiwa penting yang dialami. Pendaftaran penduduk dan pencatatan sipil tersebut kemudian akan diabadikan dalam sebuah dokumen, yakni dokumen kependudukan. Sebagaimana dijelaskan dalam Undang-Undang No. 24 Tahun 2013 tentang Administrasi Kependudukan Pasal 1 ayat (15) berbunyi "Pencatatan sipil adalah pencatatan peristiwa penting yang dialami oleh seseorang dalam register pencatatan sipil pada instansi pelaksana". ${ }^{4}$

Dokumen kependudukan adalah dokumen resmi yang diterbitkan oleh
Instansi Pelaksana yang mempunyai kekuatan hukum sebagai alat bukti autentik yang dihasilkan dari pelayanan Pendaftaran Penduduk dan Pencatatan Sipil. ${ }^{5}$

Sebagai alat bukti autentik, dokumen kependudukan merupakan sesuatu yang wajib dimiliki oleh setiap warga negara. Di antaranya adalah kartu keluarga (KK), kartu tanda penduduk elektronik (KTP-el), dan akta pencatatan sipil (Akta Kelahiran, Akta Kematian, Akta Perceraian, Akta Pengakuan Anak dll). Meskipun memiliki dokumen kependudukan adalah suatu kewajiban bagi setiap warga negara ternyata masih banyak juga masyarakat yang lalai dan enggan mengurus dokumen tersebut. Hal ini disebabkan oleh dua aspek, pertama murni dari individunya sendiri seperti menyepelekan hal yang seharusnya menjadi prioritas, kedua mengingat masih buruknya pelayanan sehingga masyarakat merasa anti untuk berurusan dengan birokrasi. Masih dijumpainya pelayanan yang ribet, berbelibelit, lama juga tidak adanya kepastian waktu, mahal dan jauhnya akses ke pusat pelayanan semakin membuat masyarakat abai dengan kebutuhan yang akan menopangnya dalam menjalani kehidupan sebagai warga negara, pasalnya dokumen kependudukan merupakan kunci untuk dapat mengakses segala pelayanan publik.

Lahirnya Undang-Undang No. 24 Tahun 2013 yang merupakan perubahan atas Undang-Undang No. 23 Tahun 2006 tentang Administrasi Kependudukan pada akhir tahun 2013 sebagai tindak lanjut dari Putusan Mahkamah Konstitusi No. 18/ PUU-XI/2013 tanggal 30 April 2013 telah membawa perubahan yang cukup mendasar dalam penyelenggaraan administrasi kependudukan di Indonesia sebagaimana tercantum dalam SuratEdaran Menteri Dalam Negeri Republik Indonesia No. 470/327/SJ tanggal 17 Januari 2014 tentang Perubahan Kebijakan dalam Penyelenggaraan Administrasi Kependudukan. 
Salah satu poin penting dalam perubahan kebijakan penyelenggaraan administrasi yang menjadi amanat dari Undang-Undang No. 24 Tahun 2013 adalah pada pelayanannya, yakni pelayanan stelsel aktif. Pelayanan administrasi kependudukan yang semula diwajibkan aktif adalah penduduk diubah menjadi pelayananan dengan stelsel aktif di mana pemerintah diwajibkan aktif melalui pelayanan jemput bola atau pelayanan keliling. ${ }^{6}$

Perubahan penyelenggaraan pelayanan ini dilakukan dalam rangka peningkatan pelayanan administrasi kependudukan sejalan dengan tuntutan pelayanan administrasi kependudukan yang profesional, memenuhi standar teknologi informasi, dinamis, tertib dan tidak diskriminatif dalam pencapaian standar pelayanan minimal menuju pelayanan prima yang menyeluruh untuk mengatasi permasalahan kependudukan. ${ }^{7}$

Selain itu perubahan ini juga diharapkan dapat memberikan pemenuhan hak-hak administrasi penduduk dalam pelayanan publik serta memberikan perlindungan yang berkenaan dengan penerbitan dokumen kependudukan tanpa ada perlakuan yang diskriminatif melalui peran aktif pemerintah.

Kelebihan-kelebihan dalam penggunaan teknologi informasi dan komunikasi (TIK) dirasa lebih banyak memberikan dampak positif dibandingkan dengan cara manual atau tradisional. Dengan penggunaan TIK kecepatan, kemudahan, transparansi, serta biaya yang lebih murah dapat dirasakan dalam memberikan informasi dan pelayanan kepada masyarakat, karena pemerintah menaungi segala macam aspek keperluan masyarakat dari lahir sampai mati maka tidak dapat dipungkiri kewajiban pemerintah baik pusat maupun daerah untuk mendorong kinerjanya supaya bisa mengikuti percepatan teknologi saat ini. Hal ini tidak hanya berlaku di Indonesia, tetapi pemerintahan seluruh dunia pada saat ini mengalami tantangan globalisasi yang sama yang dipicu oleh perkembangan teknologi informasi baik dalam kehidupan ekonomi, politik, pemerintahan,dan sosial budaya. Perubahan tersebut mengarah pada terbentuknya dunia tanpa batas (borderless world). Peristiwa penting yang terjadi pada suatu negara secara cepat dapat diakses oleh masyarakat di negara pada belahan dunia yang lain.

Tuntutan dari masyarakat era modern dalam percepatan pelayanan dan transparansi pemerintahan juga menjadi salah satu cambukan keras bagi Pemerintahan dalam mencari solusi dan inovasi. "Solusi berarti penyelesaian; pemecahan (masalah dan sebagainya); jalan keluar" (Kamus Besar Bahasa Indonesia). Dalam UU No. 18 Tahun 2002 pengertian "Inovasi adalah kegiatan penelitian, pengembangan, dan/atau perekayasaan yang bertujuan mengembangkan penerapan praktis nilai dan konteks ilmu pengetahuan yang baru, atau cara baru untuk menerapkan ilmu pengetahuan dan teknologi yang telah ada ke dalam produk atau proses produksi". Merujuk dari pengertian solusi dan inovasi maka dapat disimpulkan bahwa pemerintah harus mencari jalan keluar guna penyelesaian masalah dengan pengembangan ilmu pengetahuan dan teknologi yang baru dengan evaluasi yang bertujuan untuk pencapaian hasil yang lebih baik. Dalam hal ini maka muncullah gagasan tentang electronic government atau biasa kita sebut dengan E-Gov. E-government merupakan sebuah awal perubahan paradigma pemerintahan yang semula berupa pemerintahan yang sentralistik menuju kepada customer centric. Perubahan paradigma ini berdampak baik bagi pelayanan publik yang identik dengan birokrasi yang kaku menjadi pelayanan yang mudah dan sesuai dengan kebutuhan masyarakat.

Electronic government di Indonesia inisiatifnya sudah dimulai sejak 2003 seiring dengan keluarnya Inpres No. 
3/2003, walaupun kondisi penerapannya di lapangan masih sangat bervariasi. Agar kebijakan pengembangan e-government dapat dilaksanakan secara sistematik dan terpadu, maka masih diperlukan peraturanperaturan, standarisasi dan panduan (pedoman) yang konsisten dan saling mendukung. Dengan dikeluarkannya Inpres mengenai E-gov banyak Pemerintah Daerah Berlomba-lomba membuat inovasi-inovasi terbaru di bidang teknologi informasi (TI).

Penerapan e-gov dalam pelayanan publik diharapkan mampu memperbaiki kualitas dan kinerja Pemerintah Daerah, salah satu pelayanan publik yang paling penting untuk diperbaiki dan dibenahi adalah masalah pelayanan administrasi kependudukan dan pencatatan sipil. Dalam hal ini, yang dimaksud dengan administrasi kependudukan menurut Undang-Undang No. 24 Tahun 2013 Pasal 1 adalah "sebagai rangkaian kegiatan penataan dan penertiban dokumen dan Data Kependudukan melalui Pendaftaran Penduduk, Pencatatan Sipil, pengelolaan informasi Administrasi Kependudukan serta pendayagunaan hasilnya untuk pelayanan publik dan pembangunan sektor lain".

Dan pelayanan kependudukan yang paling pertama harus diperbaiki adalah pembuatan akta kelahiran bagi semua warga Negara Indonesia. Pentingnya kepemilikan akta kelahiran bagi setiap masyarakat di Indonesia dijelaskan dalam Peraturan Menteri Dalam Negeri Republik Indonesia No. 9 Tahun 2016 Alinea pertama (C) tentang percepatan peningkatan cakupan kepemilikan akta kelahiran, menjelaskan bahwa "Kepemilikan akta kelahiran sebagai wujud pengakuan negara atas identitas anak yang masih rendah, sehingga perlu adanya percepatan dalam kepemilikan akta kelahiran".

Fungsi akta kelahiran bagi seseorang antara lain sebagai dasar identitas diri dalam mengurus Kartu Tanda Penduduk (KTP), Kartu Keluarga (KK), Paspor,
Pendaftaran Sekolah, Pernikahan, Asuransi serta mengurus hak ahli waris. Akta kelahiran adalah salah satu identitas yang dapat membuktikan bahwa orang yang bersangkutan memiliki kejelasan status sebagai Warga Negara Indonesia yang mempunyai kekuatan hukum tetap dan mempunyai kedudukan hukum yang sama. Sesuai dalam ketentuan Pasal 27 ayat (1) UUD 1945 bahwa "segala warga Negara bersamaan kedudukannya di dalam hukum dan pemerintahan itu dengan tidak ada kecualinya".

Setiap penduduk di Indonesia wajib memiliki Akta Kelahiran seperti yang sudah dijelaskan dalam Undang-Undang No. 23 Tahun 2006 Pasal 2 dan 3. Pasal 2 menjelaskan bahwa "Setiap penduduk mempunyai hak untuk memperoleh: 1) Dokumen Kependudukan; 2) Pelayanan yang sama dalam Pendaftaran Penduduk dan Pencatatan Sipil; 3) Perlindungan atas Data Pribadi; 4) Kepastian hukum atas kepemilikan dokumen; 5) Informasi mengenai data hasil Pendaftaran Penduduk dan Pencatatan Sipil atas dirinya dan/atau keluarganya; dan 6) Ganti rugi dan pemulihan nama baik sebagai akibat kesalahan dalam Pendaftaran Penduduk dan Pencatatan Sipil serta penyalahgunaan Data Pribadi oleh Instansi Pelaksana.

Pasal 3 menjelaskan bahwa: "Setiap Penduduk wajib melaporkan Peristiwa Kependudukan dan Peristiwa Penting yang dialaminya kepada Instansi Pelaksana dengan memenuhi persyaratan yang diperlukan dalam Pendaftaran Penduduk dan Pencatatan Sipil”. Pemerintah memiliki kewajiban untuk memenuhi hak anak memperoleh akta kelahiran tercantum dalam Pasal 28 ayat (1) Undang-Undang No. 23 Tahun 2002 tentang Perlindungan Anak yang berbunyi: "Pembuatan Akta Kelahiran menjadi tanggung jawab pemerintah yang dalam pelaksanaannya diselenggarakan serendah-rendahnya pada tingkat kelurahan/desa. Selanjutnya, dalam ayat (3) 
juga disebutkan bahwa: "pembuatan akta kelahiran ini tidak dipungut biaya”. Walaupun sudah ada jaminan dari pemerintah bahwa setiap bayi yang lahir akan memiliki akta secara cuma-cuma, tetapi masih ada saja Warga Negara Indonesia yang tidak memiliki akta kelahiran. Banyaknya keterbatasan seperti akses pelayanan yang sulit dijangkau oleh masyarakat, kurangnya sosialisasi yang diterima masyarakat akan pentingnya kepemilikan akta kelahiran dan layanan prosedural yang berbelit belit. Hal ini yang mengakibatkan rendahnya minat masyarakat dalam pembuatan Akta kelahiran.

Terletak di bagian barat Ibu Kota, Kota Tangerang terus berupaya untuk bisa sejajar dengan DKI Jakarta atau kota cerdas lainnya di Indonesia. Mereka pun berusaha mengembangkan berbagai sistem digital untuk memudahkan pelayanan masyarakat. Wali Kota Tangerang Arief Rachadiono Wismansyah, mengungkapkan, sebagai kota metropolitan maka Kota Tangerang tidak lepas dari berbagai persoalan yang sama dengan kota lainnya di tanah air, mulai dari kemacetan, sampah, tata ruang kota, migrasi penduduk, kemiskinan, bencana alam, kriminalitas dan masih banyak lagi. Selain butuh peran serta dari berbagai pihak, kota berpenduduk \pm 2 juta warga ini mengembangkan konsep Tangerang LIVE, yaitu liveable (kota yang layak dihuni), investable (kota yang layak investasi), visitable (kota yang layak dikunjungi) dan ecity (kota cerdas) untuk memecahkan masalah dan tantangan dinamika perkotaan.

Tangerang LIVE dibentuk atas dasar Instruksi Presiden No. 3 Tahun 2003 tentang Kebijakan dan Strategi Nasional Pengembangan E-Government dan Peraturan Wali Kota Tangerang No. 96 Tahun 2014 tentang Rencana Induk Teknologi Informasi dan Komunikasi Kota Tangerang Tahun 20152018 serta Peraturan Wali Kota Tangerang No. 2 Tahun 2016 tentang Pemanfaatan Teknologi Informasi dan Komunikasi. Hal ini dikarenakan adanya tuntutan dan kebutuhan informasi yang cepat dan tepat dari lingkungan internal seperti Kelurahan, Kecamatan serta Satuan Kerja Pemerintah Daerah Kota Tangerang lainnya kepada lingkungan eksternal seperti pemerintahan provinsi, pemerintahan pusat, masyarakat dan investor dalam rangka mewujudkan sistem pemerintahan yang baik. Pelaksanaan pengembangan e-Government tersebut bisa terlaksana dengan baik, jika sesuai dengan Inpres No. 3 Tahun 2003

"Dalam memaknai perkembangan teknologi Pemerintah Kota Tangerang senantiasa berupaya mengikuti perkembangan teknologi melalui pemanfaatan dan peningkatan sumber daya manusia dalam teknologi informasi dan komunikasi (TIK), perangkat keras serta perangkat lunak dalam penyelenggaraan pemerintahan dan berhasil mengembangkan ekosistem TIK dengan penyelenggaraan pemerintahan secara online," ujar Wali Kota Tangerang, Arief Rachadiono Wismansyah.

Menjadi salah satu dari bagian inovasi Tangerang LIVE di Kota Tangerang adalah dengan diluncurkannya pelayanan Akta Kelahiran Online. Tantangan utama Pemerintah Kota Tangerang dalam peningkatan pelayanan akta kelahiran adalah kesadaran masyarakat Kota Tangerang akan pentingnya kepemilikan akta kelahiran merupakan salah satu aspek penghambat utama dalam pencapaian target pembuatan aktakelahiran, halinidilandasioleh minimnya manfaat yang dirasakan masyarakat akan kepemilikan akta kelahiran berbeda dengan Kartu Tanda Penduduk (KTP) atau Kartu Keluarga (KK) yang memiliki peran besar bagi kehidupan masyarakat luas. Serta proses pembuatan akta kelahiran yang berbelitbelit dan dianggap merepotkan juga menjadi faktor utama mengapa masyarakat di Kota Tangerang tidak menganggap kepemilikan akta kelahiran itu penting. Padahal telah diatur dalam Undang-Undang No. 24 Tahun 2013 Pasal 27 ayat (1) yang berbunyi "setiap kelahiran wajib dilaporkan oleh penduduk 
kepada instansi pelaksana setempat paling lambat 60 (enam puluh) hari sejak kelahiran".

Berdasarkan data rekapitulasi dari Dinas Kependudukan dan Catatan Sipil Kota Tangerang pada 2015 diketahui ada kenaikan yang signifikan dalam kepemilikan akta kelahiran pada anak usia 0 bulan s.d. 18 tahun hal ini dikarenakan Wali Kota Tangerang berinovasi untuk mendekatkan pelayanan ke masyarakat serta memangkas birokrasi yang sangat berpengaruh terhadap peningkatan minat masyarakat Kota Tangerang untuk pembuatan akta kelahiran secara online. Inovasi pembuatan akta kelahiran secara online di Kota Tangerang telah dimulai sejak 2015 dengan dasar pelayanan akta pencatatan sipil di Kecamatan, yaitu UU No. 23 Tahun 2006 tentang Administrasi Kependudukan, pada Pasal 8 ayat (3) "Pelayanan Pencatatan Sipil pada tingkat kecamatan dilakukan oleh UPTD Instansi Pelaksana dengan kewenangan menerbitkan Akta Pencatatan Sipil" dan Pasal 11, yaitu (1) Pejabat Pencatatan Sipil mempunyai kewenangan melakukan verifikasi kebenaran data, melakukan pembuktian pencatatan atas nama jabatannya, mencatat data dalam register akta Pencatatan Sipil, menerbitkan kutipan akta Pencatatan Sipil, dan membuat catatan pinggir pada akta-akta Pencatatan Sipil. (2) Ketentuan lebih lanjut mengenai pedoman pengangkatan dan pemberhentian serta tugas pokok Pejabat Pencatatan Sipil sebagaimana dimaksud pada ayat (1) diatur dalam Peraturan Menteri.

Sementara itu, Perpres No. 25 Tahun 2008 tentang Persyaratan dan Tata Cara Pendaftaran Penduduk dan Catatan Sipil Pasal 1 ayat (24) "Unit Pelaksana Teknis Dinas Instansi Pelaksana, selanjutnya disingkat UPTD Instansi Pelaksana, adalah satuan kerja di tingkat kecamatan yang melaksanakan pelayanan Pencatatan Sipil dengan kewenangan menerbitkan akta".

Pembuatan akta kelahiran ini memiliki estimasi selesai empat belas hari kerja dan dalam pelaksanaannya operatorlah yang bertugas menginput, melaporkan berkas dan mengambil akta kelahiran yang sudah selesai dikerjakan di Dinas Kependudukan dan Catatan Sipil Kota Tangerang dengan di bawah pengawasan Kasi Tata Pemerintahan masing-masing kelurahan sebagai penanggung jawab. Masyarakat sebagai pemohon selanjutnya hanya harus datang kembali ke kelurahan untuk mengambil akta kelahiran sesuai dengan tanggal yang telah ditentukan oleh operator. Dengan kemudahan dalam pembuatan akta kelahiran yang sudah dilaksanakan di Kota Tangerang membawa hasil yang sangat signifikan bagi peningkatan persentase pencapaian hasil pembuatan akta kelahiran yang harus dicapai oleh Dinas Catatan Sipil dan Kependudukan Kota Tangerang. Dengan inovasi ini diharapkan nantinya Dinas Kependudukan dan Pencatatan Sipil Kota Tangerang dalam memperoleh persentase pembuatan akta kelahiran melebihi dari standar yang diberikan oleh Kementerian Kependudukan, yaitu sebesar $85 \%$ warga Kota Tangerang harus sudah memiliki akta kelahiran baik untuk diri sendiri maupun anak-anaknya. Mengingat pentingnya seorang anak memiliki akta kelahiran sebagai haknya sejak lahir yang akan digunakan untuk mendapatkan hak-hak yang lain seperti mendapatkan pendidikan. Pendaftaran sekolah dibutuhkan akta kelahiran sebagai persyaratan mutlak dalam mendaftarkan anak ke sekolah, serta saat anak sudah berumur 17 tahun akta kelahiran digunakan untuk permohonan pembuatan E-KTP.

Dengan dilaksanakannya inovasi pembuatan akta kelahiran online ini perkembangan data pembuatan akta kelahiran terbaru di Kota Tangerang pada 2017 diperoleh data paling tinggi terdapat di Kelurahan Uwungjaya Kecamatan Karawaci dengan jumlah pembuatan 794 akta kelahiran dan pada 2018 pelayanan pembuatan akta kelahiran paling tinggi di Kelurahan Cibodas 
Kecamatan Cibodas. Sedangkan Kelurahan Nambojaya Kecamatan Karawaci pada 2017 dan 2018 tingkat pembuatan akta kelahiran online-nya sangat rendah hanya sekitar 36 akta kelahiran pada 2017 dan 8 akta kelahiran pada 2018. Hal ini menjadi perhatian khusus penelitian ini melihat rendahnya permohonan pembuatan akta kelahiran online di Kelurahan Nambojaya Kecamatan Karawaci. Maka dari uraian di atas penelitian ini akan mengambil lokus di Kelurahan Nambojaya Kecamatan Karawaci dan akan ditelusuri lebih dalam bagaimana inovasi pembuatan akta kelahiran online di Kelurahan Nambojaya Kecamatan Karawaci Kota Tangerang ini berlangsung, apakah ada kendala-kendala permasalahan di dalam penyelenggaraan pemerintahan daerah adalah sebagai bentuk evaluasi terhadap penyelenggaraan sistem otonomi daerah, karena dalam penyelenggaraan otonomi daerah di Indonesia, masalah pelayanan menjadi salah satu tolok ukur keberhasilan otonomi daerah. Dengan adanya penelitian tentang inovasi pelayanan akta kelahiran online di Kota Tangerang ini dapat dijadikan sebagai role model atau percontohan bagi daerah-daerah lain, dan sekaligus berupaya menghasilkan model-model pelayanan publikbaruyanglebih relevan bagikebutuhan masyarakat. Dengan demikian penelitian ini dapat memberikan sumbangsih gagasan bagi para pemangku kebijakan di daerah.

\section{KERANGKA PEMIKIRAN}

Hakikat pelayanan publik adalah pemberian pelayanan prima kepada masyarakat yang merupakan perwujudan kewajiban aparatur pemerintah/pemberi jasa sebagai abdi masyarakat. Untuk dapat memberikan pelayanan yang memuaskan atau produk pelayanannya berkualitas, penyelenggara pelayanan harus memenuhi prinsip-prinsip kualitas pelayanan. Menurut Parasuraman dkk yang dikutip oleh Fandy Tjiptono, (2000: 70) ada beberapa kriteria yang menjadi dasar penilaian konsumen terhadap pelayanan yaitu 1) Tangible, atau bukti fisik, yaitu kemampuan dalam menunjukkaneksitensinya kepada pihak eksternal. Yang dimaksudkan bahwa penampilan dan kemampuan sarana dan prasarana fisik dan keadaan lingkungan sekitarnya merupakan bukti nyata dan pelayanan yang diberikan; 2) Reliability, atau kehandalan, yaitu kemampuan dalam memberikan pelayanan sesuai yang dijanjikan secara akurat dan terpercaya; 3) Responsiveness, atau tanggapan, yaitu suatu kemauan untuk membantu dan memberikan pelayanan yang cepat dan tepat kepada masyarakat dengan menyampaikan informasi yang jelas. 4) Assurance, atau jaminan dan kepastian, yaitu pengetahuan, kesopansantunan, dan kemampuan para pegawai untuk menumbuhkan rasa percaya terhadap pelanggan.Terdiri dari beberapa komponen di antaranya adalah komunikasi, kredibilitas, keamanan, kompetensi dan sopan santun. 5) Empathy, yaitu memberikan perhatian yang tulus dan bersifat individual atau pribadi yang diberikan kepada pelanggan dengan berupaya memahami keinginan pelanggan.

Indrajit (2011: 66) menyebutkan bahwa "terdapat beberapa elemen sukses dalam manajemen proyek e-government, antara lain: 1) Political environment merupakan suatu suasana yang menunjukkan politik proyekyangbersangkutan atau dilaksanakan. Pada praktiknya, terdapat dua tipe proyek. Pertama, Top Down Projects (TDP), yaitu hal yang berkaitan dengan eksistensi sebuah proyek yang ditentukan oleh adanya inisiatif dari lingkungan eksekutif sebagai otoritas tertinggi pemerintahan atau disponsori oleh kalangan legislatif sebagai pemberi mandat. Kedua, Bottom Up Projects (BUP), yaitu hal dilaksanakan karena adanya ide atau inisiatif dari kepala unit atau karyawan yang berada si salah satu lembaga pemerintahan atau departemen; 2) Leadership atau kepemimpinan merupakan faktor yang memiliki peran sangat penting dalam 
memengaruhi kegagalan atau keberhasilan implementasi kebijakan atau implementasi program. Faktor kepemimpinan melekat pada pihak yang memiliki tugas sebagai pemimpin dari penyelenggaraan proyek atau para manager proyek. Manager proyek memiliki tanggung jawab untuk melaksanakan sebuah proyek dari awal sampai akhir sesuai dengan siklus proyek yang dijalankan.

Selanjutnya, 3) Planning atau perencanaan merupakan tahapann awal sebelum sebuah implementasi kebijakan atau implementasi proyek dilakukan. Perencanaan dilakukan dengan tujuan untuk memproyeksikan hasil yang ingin dicapai dan untuk mengetahui tentang sejauh mana pentingnya sebuah perencanaan sebelum dilakukan implementasi kebijakan atau implementasi proyek. Perencanaan dianggap sebagai tahapann penting karena perencanaan merupakan tahapann awal di mana gambaran menyeluruh dan detail dari rencana inisiatif e-government akan diproyeksikan. Perencanaan yang baik akan memiliki secara keseluruhan karena apa yang dilaksanakan pada siklus berikutnya sebenarnya adalah pengaplikasian dari rencana besar yang telah disepakati. 4) Stakeholders merupakan salah satu elemen yang memengaruhi implementasi kebijakan atau implementasi proyek. Stakeholders juga dianggap sebagai berbagai pihak yang merasa memiliki kepentingan baik secara langsung maupun tidak langsung terhadap penyelenggaraan proyek e-government terkait. Pihak-pihak yang dianggap sebagai stakeholders utama dalam proyek e-government antara lain: pemerintah atau lembaga terkait seluruh manajemen dan karyawannya, sektor swasta, masyarakat, lembaga swadaya masyarakat, perusahaan dan lain sebagainya.

Kemudian, 5) Transparency/visibility, Penerapan e-government diharapkan dapat mewujudkan adanya transparansi dalam setiap proses yang dilakukan. Transparansi sebuah proyek e-government memiliki kaitan erat dengan keberadaan stakeholders karena harus terus tersedia seluruh data dan informasi terkait dengan keseluruhan dan status proyek yang sedang berlangsung agar dapat secara bebas diakses stakeholders yang beragam. Adanya akses informasi, yaitu terkait dengan status proyek, alokasi sumber daya, evaluasi terhadap proyek dan hal lain yang bersangkutan memiliki tujuan untuk menciptakan kredibilitas dan legitimasi yang baik bagi para penyelenggara proyek maupun stakeholders sebagai pihak yang melakukan monitoring. Adanya kemungkinan dengan keterlibatan pihakpihak yang berkepentingan mengakses data dan informasi terkait dengan proyek yang sedang berlangsung secara tidak langsung merupakan sarana pemasaran yang dinilai cukup efektif karena terlihat keseriusan pemerintah untuk selalu memberikan yang terbaik untuk rakyatnya melalui implementasi beragam proyek e-government.

Selain itu, 6) Budgets merupakan anggaran yang disediakan oleh pemerintah dan kalangan lain semacam swasta atau bantuan dari luar negeri yang sangat bergantung pada tingkat prioritas yang diberikan oleh pemerintah terhadap status proyek terkait. Kekuatan sumber daya berupa budgets yang dianggarkan pada sebuah proyek e-government merupakan salah satu elemen strategis dan sangat menentukan terkait dengan berhasil atau tidaknya pada pelaksanaan sebuah proyek; 7)Teknologi yang digunakan dalam proyek e-government sangat lebar, dari teknologi yang paling sederhana dan murah sampai dengan teknologi yang paling canggih. Keberadaan sumber daya manusia juga dianggap sebagai hal yang memengaruhi perkembangan teknologi yang digunakan, di mana semakin tinggi kualitas sumber daya manusia maka semakin canggih pula teknologi yang dikembangkan. Pemilihan teknologi yang digunakan dalam implementasi proyek e-government sangat 
tergantung pada anggaran yang disediakan. Semakin besar nilai anggaran yang ada, maka semakin canggih teknologi yang dapat dipilih dan digunakan sehingga hal tersebut akan meningkatkan probabilitas berhasilnya suatu proyek dan mencapai manfaat yang ditargetkan. Pada sisi lain, teknologi memiliki peran penting terhadap kualitas layanan publik, di mana semakin canggih teknologi yang digunakan maka masyarakat juga akan semakin mudah dalam mengakses bentuk-bentuk layanan publik secara online; 8) Innovation dalam hal ini merujuk pada kemampuan sumber daya manusia untuk melakukan inovasi-inovasi tertentu. Inovasi dalam e-government memiliki sifat yang tidak terbatas pada kemampuan untuk menciptakan produk-produk baru tertentu, tetapi yang terlibat dalam proyek harus memiliki tingkat kreativitas yang cukup terutama dalam melakukan pengelolaan terhadap proyek e-government yang ada sehingga berbagai hambatan yang sering ditemui dalam sebuah proyek dengan mudah dapat dihilangkan."

\section{METODE PENELITIAN}

\section{Desain Penelitian}

Penelitian ini merupakan penelitian kualitatif. Metode kualitatif adalah metode penelitian yang digunakan untuk menggambarkan fakta serta keteranganketerangan yang ada di lapangan, Dengan menggunakan metode penelitian kualitatif, penelitian ini bertujuan untuk mendeskripsikan mengenai kualitas pelayanan publik di Dinas Kependudukan dan Pencatatan Sipil (Dindukcapil) Kota Tangerang secara umum dan secara khusus di Kelurahan Nambojaya Kecamatan Karawaci.

\section{Penentuan Informan Penelitian}

Penentuan seseorang menjadi informan penelitian didasarkan pada kriteria kedudukan, peran, kompetensi atau keterlibatan yang relevan atau terkait dengan proses pengungkapan dan pembahasan implementasi kebijakan Surat Edaran Menteri Dalam Negeri dalam menerapkan inovasi kependudukan akta kelahiran. Untuk mengetahui orang-orang yang memenuhi kriteria tersebut dilakukan survei dan konsultasi ke sejumlah pihak. Dengan pendekatan survei dan konsultasi tersebut, selanjutnya teknis penentuan informan menggunakan snow balltechnique. Penentuan informan penelitian juga memperhatikan kesediaan yang bersangkutan.

Sesuai dengan perspektif fenomena yang dijadikan objek penelitian, perencanaan unsur-unsur informan terdiri atas: (1) Unsur Pimpinan Dinas Kependudukan; (2) Unsur ASN Dinas Kependudukan; dan (3) Para pemangku kepentingan. Jumlah informan penelitian dari masing-masing unsur ditentukan pada waktu penelitian dilaksanakan, setelah hasil penelitian yang didapat sudah dianggap optimal untuk dibahas.

\section{Sumber dan Teknik Pengumpulan Data}

Teknik penunjang dalam mendapatkan data dan informasi terkait dengan akta kelahiran penulis melakukan 1) Wawancara, Teknik wawancara adalah cara pengumpulan jenis data primer dari para informan penelitian. Konsep wawancara dirancang dengan penyusunan Pedoman Wawancara. Pedoman wawancara yang berisi pokokpokok pertanyaan (leading questions) disusun berdasarkan model implementasi kebijakan dari Indrajit: 2) Studi Pustaka, Penelusuran pustaka, yaitu dengan mencari referensi, mengumpulkan data dan informasi yang bersifat teoretis.

\section{HASIL PENELITIAN DAN PEMBAHASAN}

\section{Political Environment}

Political environment merupakan suatu suasana yang menunjukkan politik proyek yang bersangkutan atau dilaksanakan. Pada 
praktiknya, terdapat dua tipe proyek. Pertama, Top Down Projects (TDP), yaitu hal yang berkaitan dengan eksistensi sebuah proyek yang ditentukan oleh adanya inisiatif dari lingkungan eksekutif sebagai otoritas tertinggi pemerintahan atau disponsori oleh kalangan legislatif sebagai pemberi mandat. Kedua, Bottom Up Projects (BUP), yaitu hal dilaksanakan karena adanya ide atau inisiatif dari kepala unit atau karyawan yang berada si salah satu lembaga pemerintahan atau departemen.

Sinyal diberikan oleh informan penelitian bahwa kompetensi dan evaluasi merupakan sebuah rujukan sebagai tolok ukur dalam keberhasilan sebuah kebijakan yang terlaksana. Hal ini menunjukkan bahwa kejelasan proses pelaksanaan penerapan e-goverment untuk pelayanan akta kelahiran berbasis online sudah dapat dipahami sepenuhnya oleh aparatur yang bertugas di tingkat Kelurahan Nambojaya. Jelas dikemukakan bahwa pihak kelurahan sebagai eksekutor terus mengupayakan yang terbaik untuk seluruh masyarakat Kelurahan Nambojaya. Upaya ini karena semua yang dilaksanakan sudah tercakup dalam sebuah program rencana yang terintegrasi dalam sistem. Beban kerja yang teramanatkan pada Kelurahan Nambojaya, seyogyanya dapat dijalankan dengan sebaikk mungkin sehingga semua kebijakan yang tercakup dalam pelaksanaan pembuatan Akta Kelahiran online. Penerapan secara online ini dipandang cukup membantu semua kendala yang selama ini menjadi permasalahan administrasi kependudukan di Kelurahan Nambojaya. Namun, masih adanya warga yang belum sepenuhnya memahami tentang semua prosedur dan tata cara pembuatan secara online menjadi kendala tersendiri bagi aparatur kelurahan untuk dapat menyosialisasikan hal tersebut untuk menjadi lebih baik dan mudah.

\section{Leadership}

Leadership atau kepemimpinan merupakan faktor yang memiliki peran sangat penting dalam memengaruhi kegagalan atau keberhasilan implementasi kebijakan atau implementasi program. Faktor kepemimpinan melekat pada pihak yang memiliki tugas sebagai pemimpin dari penyelenggaraan proyek atau para manager proyek. Manager proyek memiliki tanggung jawab untuk melaksanakan sebuah proyek dari awal sampai akhir sesuai dengan siklus proyek yang dijalankan. Proses pembinaan dari dinas kependudukan dan catatan sipil dan Lurah Kelurahan Nambojaya dalam proses penerapan e-goverment pada pelayanan akta kelahiran berbasis online guna tercapainya penerapan e-goverment yang sesuai dengan visi dan misi Kota Tangerang.

Peran aktif instansi terkait yang memfasilitasi untuk dapat memberikan penjelasan terkait semua program yang telah direncanakan dan ditetapkan. Jelas dikemukakan bahwa pengawasan dan evaluasi perlu dilakukan oleh Disdukcapil Kecamatan Karawaci. Hal ini dibutuhkan untuk menjaga semua program dan realisasi berjalan dengan baik. Pengawasan yang berlangsung dapat berupa monitoring pelaksanaan pelayananinovasiakta kelahiran pada tiap-tiap kelurahan. Monitoring yang berlangsung mengedepankan tugas aparatur sipil negara sebagai pelayanan publik yang berorientasi pada pelayanan yang prima.

\section{Planning}

Planning atau perencanaan merupakan tahapann awal sebelum sebuah implementasi kebijakan atau implementasi proyek dilakukan. Perencanaan dilakukan dengan tujuan untuk memproyeksikan hasil yang ingin dicapai dan untuk mengetahui tentang sejauh mana pentingnya sebuah perencanaan sebelum dilakukan implementasi kebijakan atau implementasi proyek. Perencanaan dianggap sebagai tahapann penting karena perencanaan merupakan tahapann awal di mana gambaran menyeluruh dan detail dari rencana inisiatif e-government akan 
diproyeksikan. Perencanaan yang baik akan memiliki secara keseluruhan karena apa yang dilaksanakan pada siklus berikutnya sebenarnya adalah pengaplikasian dari rencana besar yang telah disepakati. Perencanaan awal terlaksananya penerapan e-goverment dalam pelayanan akta kelahiran berbasis online baik di lingkup Dinas Kependudukan dan Catatan Sipil dan Kelurahan Nambojaya.

Perencanaan pelaksanaan kebijakan tentunya memiliki payung hukum yang telah dibahas dan didiskusikan bersama. Hal ini menjadi acuan bagi ASN sebagai pelaksana kebijakan sehingga para ASN dapat melakukan kebijakan tersebut dengan penuh rasa tanggung jawab dan akan melayani sesuai dengan konsep pelayanan prima dan memberikan yang terbaik untuk para masyarakat sebagai penerima pelayanan.

Belum sepenuhnya saluran pelayanan berjalan dengan baik, karena disinyalir adanya kendala teknis. Di mana pelayanan terintegrasi oleh sistem onlineyang terkadang jaringan tersebut mengalami kendala pada sinyal sehingga pelayanan terhenti. Hal ini yang patut menjadi perhatian bagi semua pihak, baik pemberi maupun penerima pelayanan bahwa kendala teknis seperti ini di luar jangkauan para ASN sebagai pemberi pelayanan. Karena hal ini menyangkut pada provider pemberi jasa internet yang memang terintegrasi pada pelayanan secara online.

\section{Stakeholder}

Stakeholders merupakan salah satu elemen yang memengaruhi implementasi kebijakan atau implementasi proyek. Stakeholders juga dianggap sebagai berbagai pihak yang merasa memiliki kepentingan baik secara langsung maupun tidak langsung terhadap penyelenggaraan proyek e-government terkait. Pihak-pihak yang dianggap sebagai stakeholders utama dalam proyek e-government antara lain: pemerintah atau lembaga terkait seluruh manajemen dan karyawannya, sektor swasta, masyarakat, lembaga swadaya masyarakat, perusahaan dan lain sebagainya. Tetap fokus pada pelayanan publik dengan target pelayanan yang cukup realistis. Hal ini menunjukkan atau mengindikasikan bahwa pelayanan yang diberikan oleh para ASN Kelurahan Nambojaya terus semakin membaik dengan memperlihatkan semakin mendakatnya antara target yang ditetapkan dengan angka realisasi, yaitu $88 \%$.

Sejatinya para ASN dalam melayani mengedepankan pelayanan yang prima. Pelayanan prima yang tercipta melalui segala bentuk proses dan perencanaan serta kerja sama dari berbagai pihak, sehingga dengan hal tersebut dapat menciptakan sebuah target dan realisasi yang sesuai dengan harapan bersama.

Peran serta ASN aktif dalam melakukan pelayanan merupakan salah satu perwujudan pelayanan prima yang diberikan oleh para ASN dalam menyikapi dinamika pelaksanaan dan pengimplementasian seluruh kebijakan pelayanan yang telah diamanatkan dan diemban oleh para ASN. Dengan baiknya hal tersebut maka ASN dapat memberikan atau berkontribusi dalam mendukung kebijakan inovasi pelayanan akta kelahiran berbasis dengan media online. Ketegasan sekali diungkapkan oleh berbagai pihak bahwa perwujudan dan realisasi target yang maksimal dapat diciptakan melalui kerja sama antarlini atau unit kerja dalam organisasi. Kerja sama antarlini atau unit kerja di bawah pengawasan pimpinan pada pucuk organisasi. Peran aktif pucuk pimpinan organisasi dalam kontrol dan pengawasan menjadikan roda kehidupan organisasi berjalan dengan efektif.

Pencapaian standar kebijakan yang telah ditetapkan masih terus berjalan dan tetap akan selalu dimaksimalkan pencapaian tersebut. Jelas terlihat bahwa seluruh elemen ASN Kelurahan Nambojaya berperan aktif dalam pencapaian tersebut. Namun, hal 
yang perlu diperhatikan dalam pencapaian standar tersebut bahwa peran aktif ASN belum cukup sebagai faktor pendorong maksimalnya pencapaian standar tersebut. Terdapat beberapa faktor sebagai pendorong pencapaian tersebut seperti perlu adanya penunjang infrastruktur jaringan internet berupa aplikasi yang terintegrasi pada gadget masyarakat. Penunjang berupa aplikasi dapat menjadi faktor pendorong untuk dapat memaksimalkan upaya Kelurahan Nambojaya untuk dapat mencapai standar yang telah ditetapkan. Aplikasi ini diharapkan dapat memberikan kemudahan dalam melaksanakan pelayanan publik. Diharapkan dengan adanya aplikasi tersebut memberikan kemudahan bagi masyarakat dalam menerima pelayanan serta ASN yang memberikan kemudahan.

\section{Transparency/Visibility}

Penerapan e-government diharapkan dapat mewujudkan adanya transparansi dalam setiap proses yang dilakukan. Transparansi sebuah proyek e-government memiliki kaitan erat dengan keberadaan stakeholders karena harus terus tersedia seluruh data dan informasi terkait dengan keseluruhan dan status proyek yang sedang berlangsung agar dapat secara bebas diakses stakeholders yang beragam. Adanya akses informasi, yaitu terkait dengan status proyek, alokasi sumber daya, evaluasi terhadap proyek dan hal lain yang bersangkutan memiliki tujuan untuk menciptakan kredibilitas dan legitimasi yang baik bagi para penyelenggara proyek maupun stakeholders sebagai pihak yang melakukan monitoring. Adanya kemungkinan dengan keterlibatan pihakpihak yang berkepentingan mengakses data dan informasi terkait dengan proyek yang sedang berlangsung secara tidak langsung merupakan sarana pemasaran yang dinilai cukup efektif karena terlihat keseriusan pemerintah untuk selalu memberikan yang terbaik untuk rakyatnya melalui implementasi beragam proyek e-government.
Semangat dalam melayani masyarakat perlu terus digelorakan oleh pimpinan kantor Kelurahan Nambojaya kepada seluruh ASN. Dengan gelora semangat melayani diharapkan dapat memberikan sebuah pelayanan yang prima serta pencapaian maksimal. Hambatan dan rintangan kerap timbul dalam pelayanan yang diberikan oleh Kelurahan Nambojaya sehingga informan memandang perlu adanya pembimbingan dan penyelarasan yang maksimal dari Dinas terkait, dalam hal ini adalah Dinas Kependudukan dan Catatan Sipil Kota Tangerang. Pembinaan dan Penyelarasan dipandang sangat perlu karena dapat memengaruhi kelancaran dan konsistensi maksimalnya peranan para pelayan masyarakat. Oleh sebab itu penulis memandang perlu dan penting proses pembinaan dan penyelarasan setiap kegiatan yang ditujukan kepada pelayanan masyarakat.

\section{Budget}

Budgets merupakan anggaran yang disediakan oleh pemerintah dan kalangan lain semacam swasta atau bantuan dari luar negeri yang sangat bergantung pada tingkat prioritas yang diberikan oleh pemerintah terhadap status proyek terkait. Kekuatan sumber daya berupa budgets yang dianggarkan pada sebuah proyek e-government merupakan salah satu elemen strategis dan sangat menentukan terkait dengan berhasil atau tidaknya pada pelaksanaan sebuah proyek. Dukungan anggaran daerah Pemerintah Kota Tangerang dalam mendukung penerapan e-government yang diterapkan kepada aparatur dalam menjalankan tugas pencatatan kependudukan terutama Akta Kelahiran di Kelurahan Nambojaya Kecamatan Karawaci Kota Tangerang. Keterbatasan anggaran untuk pelayanan kependudukan dan catatan sipil dirasakan menjadi sebuah kendala tersendiri dalam memberikan pelayanan kepada masyarakat. Kendala anggaran 
disinyalir menjadi penghambat karena kelurahan tidak memiliki kuasa anggaran untuk dapat mengatasi permasalahan yang timbul karena adanya peralatan atau jaringan yang rusak. Hal ini perlu adanya koordinasi kepada Dinas Kependudukan dan Catatan Sipil sebagai kuasa anggaran untuk dapat mengatasi permasalahan yang timbul pada setiap kelurahan dalam pelayanan kependudukan dan catatan sipil.

Anggaran yang mencukupi belum dapat memenuhi target yang telah ditetapkan. Hal ini terkendala bahwa anggaran tidak dikuasakan kepada kelurahan jadi target tidak maksimal dilakukan. Belum mencapainya target dalam pelayanan kependudukan dan catatan sipil khususnya pelayanan Akta Kelahiran secara online disebabkan karena tidak adanya anggaran pelayanan akta kelahiran secara online dari Pemerintah Kota Tangerang kepada setiap kelurahan. Hal ini menyebabkan pelayanan tersendat apabila ada perangkat dan peralatan yang rusak atau terkendala. Sebuah pekerjaan rumah yang cukup besar bagi jajaran Pemerintah Kota Tangerang untuk dapat berbenah dalam merancang dan mengaplikasikan sektor anggaran (budgeting). Karena segala bentuk kegiatan serta pelaksanaannya tidak lepas dari sumber daya pendanaan. Hal ini menjadi kendala tersendiri bagi Kelurahan Nambojaya dalam memberikan pelayanan Akta Kelahiran secara online, mengingat kuasa anggaran berada di tangan Dinas Kependudukan dan Catatan Sipil Kota Tangerang.

\section{Teknologi}

Teknologi yang digunakan dalam proyek e-government sangat lebar, dari teknologi yang paling sederhana dan murah sampai dengan teknologi yang paling canggih. Keberadaan sumber daya manusia juga dianggap sebagai hal yang memengaruhi perkembangan teknologi yang digunakan, di mana semakin tinggi kualitas sumber daya manusia maka semakin canggih pula teknologi yang dikembangkan.
Pemilihan teknologi yang digunakan dalam implementasi proyek e-government sangat tergantung pada anggaran yang disediakan. Semakin besar nilai anggaran yang ada, maka semakin canggih teknologi yang dapat dipilih dan digunakan sehingga hal tersebut akan meningkatkan probabilitas berhasilnya suatu proyek dan mencapai manfaat yang ditargetkan. Di sisi lain, teknologi memiliki peran penting terhadap kualitas layanan publik, di mana semakin canggih teknologi yang digunakan maka masyarakat juga akan semakin mudah dalam mengakses bentuk-bentuk layanan publik secara online. Ketersediaan jaringan internet yang stabil untuk mendukung penerapan e-government dalam pelayanan akta kelahiran kepada aparatur dalam menjalankan tugas pencatatan kependudukan terutama Akta Kelahiran di Kelurahan Nambojaya Kecamatan Karawaci Kota Tangerang. Sama halnya dengan sektor penganggaran, sejatinya seluruh perangkat dan kelengkapannya telah disediakan oleh pihak kecamatan, sehingga pihak kelurahan dan jajarannya hanya sebagai pelaksana dalam memberikan pelayanan yang maksimal kepada masyarakat.

Penerapan serta ketersediaan teknologi yang tercipta dalam melayani masyarakat merupakan perwujudan optimalnya pelayanan yang diberikan oleh Kelurahan Nambojaya. Tentunya, peranan Kelurahan Nambojaya tidak berdiri sendiri dalam menciptakan dan memberikan pelayanan yang terbaik bagi masyarakat dalam wilayah Kelurahan Nambojaya, peranan tersebut juga dapat tercipta karena adanya kolaborasi antara Kelurahan, Kecamatan dan Dinas Kependudukan dan Catatan Sipil.

\section{Innovation}

Innovation dalam hal ini merujuk pada kemampuan sumber daya manusia untuk melakukan inovasi-inovasi tertentu. Inovasi dalam e-government memiliki sifat yang tidak terbatas padakemampuan untukmenciptakan produk-produk baru tertentu, tetapi yang 
terlibat dalam proyek harus memiliki tingkat kreativitas yang cukup terutama dalam melakukan pengelolaan terhadap proyek e-government yang ada sehingga berbagai hambatan yang sering ditemui dalam sebuah proyek dengan mudah dapat dihilangkan." Harapan untuk terus meningkatkan inovasi guna menunjang pelayanan, khususnya pelayanan Akta Kelahiran secara online. Karena dengan inovasi yang berbasis teknologi dapat disinyalir memudahkan segala bentuk pelayanan. Inovasi tersebut tentunya berkat adanya masukan dari berbagai pihak yang akan dilaksanakan oleh pihak pelaksana dalam hal ini adalah pihak Kelurahan Nambojaya.

Pelaksanaan dan persiapan kegiatan dalam menunjang terbentuknya inovasi dan kreativitas, sangat diperlukan oleh ASN di setiap Kelurahan pada Kecamatan Karawaci Kota Tangerang. Dengan terciptanya kegiatan seperti Bimbingan Teknis serta Pendidikan dan Pelatihan dapat mendorong untuk menciptakan sumber daya manusia yang handal dan mumpuni dalam melaksanakan pelayanan berbasis online.

\section{SIMPULAN}

Berdasarkan hasil penelitian serta analisis pembahasan penulis mengajukan simpulan hasil penelitian sesuai dengan rumusan masalah yang diajukan yaitu

1. Analisis pembuatan akta kelahiran online di Kelurahan Nambojaya Kecamatan Karawaci Kota Tangerang, yakni dapat disimpulkan sebagai berikut: a) Political environment masih perlu adanya evaluasi dan peningkatan kemampuan ASN; b) Leadership kurangnya pembinaan kepada ASN di Kelurahan yang dilakukan oleh Disdukcapil dan pihak Kecamatan; c) Planning yang dinilai sudah sesuai dengan payung hukum yang berlaku, yakni Peraturan Wali Kota No. 96 Tahun 2016 tentang Rencana Induk Teknologi Informasi dan Komunikasi Kota Tangerang tahun 2016-2018 dan Peraturan Wali Kota No. 2 Tahun 2016 tentang Pemanfaatan Teknologi Informasi dan Komunikasi; d) Stakeholder dalam memengaruhi implementasi kebijakan yang diselenggarakan oleh Kelurahan Nambojaya dalam Pelayanan Akta Kelahiran berbasis online mesih belum mencapai target pencapaian yang telah ditetapkan; e) Transparency/Visibility pengawasan yang tercipta masih lemah, hal ini karena monitoring yang dilakukan oleh pihak Kecamatan ataupun Dinas Kependudukan dan Catatan Sipil masih belum berkesinambungan dalam mengawasi pelayanan Akta Kelahiran Berbasis Online; f) Pihak Kelurahan Nambojaya bukan sebagai kuasa anggaran (Budget) hal ini menjadi kendala tersendiri bagi kelurahan untuk dapat mengatasi permasalahan yang timbul pada Pelayanan Akta Kelahiran berbasis online;g) Pemanfaatanteknologi yang masih kurang dioptimalkan oleh para ASN. Hal tersebut disinyalir bahwa para ASN belum memahami sepenuhnya akan penerapan teknologi tersebut sehingga membutuhkan bimbingan dan pengawasan; h) Aparatur Sipil Negara belum sepenuhnya melakukan innovation dalam memberikan pelayana yang baik. Saat ini yang ada masih mengikuti alur atau tata cara yang diberlakukan.

2) Kendala-kendala yang menghambat Inovasi pelayanan akta kelahiran online di Kelurahan Nambojaya Kecamatan Karawaci Kota Tangerang, yaitu belum adanya keterpaduan antara Kelurahan Nambojaya dengan Kecamatan Karawaci dan Dinas Kependudukan dan Catatan Sipil Kota Tangerang. Keterpaduan tersebut dalam hal political environment, leadership, planning, stakeholders, transparency/visibility, budgets, technology, innovation. 


\section{SARAN}

Berdasarkan simpulan yang diperoleh, maka saran-saran yang disampaikan adalah sebagai berikut.

\section{Saran Praktis}

1. Disarankan kepada Pimpinan Kelurahan Nambojaya untuk dapat meningkatkan motivasi diri Aparatur untuk dapat melayani masyarakat dengan baik, yaitu melalui tugas belajar atau pelatihan manajerial dan pelatihan administrasi;

2. Disarankan kepada Pimpinan Kelurahan Nambojaya untuk dapat meminimalkan praktik percaloan yang kerap muncul dalam kepengurusan akta kelahiran;

\section{Saran Teoretis}

Memandang konteks yang lebih luas lagi penulis memberikan saran teoretis berikut.

1. Kepada Rektor Institut Pemerintahan Dalam Negeri (IPDN) kiranya hasil penelitian ini dapat dijadikan rujukan sebagai pengembangan terapan Ilmu Pemerintahan terutama pada program pascasarjana strata dua IPDN, sehingga khazanah keilmuan pada IPDN menjadi berwarna dan beragam;

2. Kepada peneliti selanjutnya, karena konteks metode penelitian dengan menggunakan metode kualitatif, kiranya pada peneliti selanjutnya dapat memberikan keberagaman metode penelitian dengan mengangkat dari sudut padang kuantitatif dengan objek yang hampir sama.

\section{(Footnotes)}

1. Undang-Undang No. 23 Tahun 2014 tentang Pemerintahan Daerah, Pasal 1 ayat 11

2. Ibid, Pasal 9 ayat (1)

3. Undang-Undang No. 24 Tahun 2013 tentang Administrasi Kependudukan Pasal 1 ayat (1)
4. Ibid, Pasal 1 ayat (10)

5. Ibid, Pasal 1 ayat (8)

6. Surat Edaran Mendagri No. 470/327/ SJ Tanggal 17 Januari 2014, tentang Perubahan Kebijakan dalam Penyelenggaraan Administrasi Kependudukan.

7. Undang-Undang No. 24 Tahun 2013 tentang Administrasi Kependudukan

\section{DAFTAR RUJUKAN}

A.S. Homby. 1995. Oxford Advanced Learner's Dictionary of Current English. Oxford University Press.

Abdul Kadir, 2003, "Pengenalan Sistem Informasi", Andi, Yogyakarta

Alter, Steven., 1992. Information systems: A Management Perspective. Benjamin/ Cummings, California.

Andrianto, Nico.2007. Transparansi dan Akuntabilitas Publik Melalui e-Government. Malang: Bayumedia Publishing.

Budi Winarno. 2012. Kebijakan Publik Teori, Proses, dan Studi Kasus. Yogyakarta: CAPS.

Everett M. Rogers. 1983. Diffusion of Innovations. London: The Free Press.

Febliany, I., Fitriyah, N., \& Paselle, E. (2014). Efektivitas Pelayanan Terpadu Satu Pintu terhadap Penyerapan Investasi di Kalimantan Timur (Studi pada Badan Perizinan dan Penanaman Modal Daerah Provinsi Kalimantan Timur). eJournal Administrative Reform, 2014, 2 (4): 24612472

Gunawan, Resta. 2013. Penggunaan Citra Satelit Quickbird untuk Penentuan Prioritas Lokasi Perumahan di Kecamatan Banguntapan Kabupaten Tangerang, Skripsi. Yogyakarta: Universitas Gajah Mada

Hamdi, Muchlis. 2014. Kebijakan Publik: Proses, Analisis, dan Partisipasi. Bogor: Ghalia Indonesia.

Indrajit, Richardus Eko (2005). E-Government in action. Yogyakarta: Andi Offset. 
Indrajit, Richardus Eko.2011.Peranan Teknologi Informasi dan Internet.Yogyakarta: Andi Offset.

Jong, De \& Den Hartog,. 2003. "Leadership as a determinant of innovative behavior". A Conceptual framework. https: //www. eim.net/pdf-ez/H200303.pdf.

Lucas, Henry J. 2000. Information Technology For Management, Irwin/McgrawHill

Robbins, Stephen P., 1994. Teori Organisasi: Struktur, Desain dan Aplikasi, Alih Bahasa Jusuf Udaya, Jakarta, Arcan

Soemartono, Triyuni dan Sri Hendrastuti, Administrasi Kependudukan Berbasis Registrasi, Yayasan Bina Profesi Mandiri, Bandung, 2011

Syafri, Wirman dan Israwan Setyoko. 2010. Implementasi Kebijakan Publik dan Etika Profesi Pamong Praja. Sumedang: Alqaprint Jatinangor.

\section{Jurnal}

Widhiastiti, Pascarani dan Wismayanti, (2016), Implementasi Pelayanan Akta Kelahiran Online di Kota Denpasar.

Erin Rahmawati, Retno Suryawati, Inovasi Pelayanan Akta Kelahiran Anak oleh Dinas Kependudukan dan Pencatatan Sipil (Dispendukcapil) di Kota Surakarta, Fakultas Ilmu Sosial dan Politik, Universitas Sebelas Maret Surakarta.

Ajayi, Chiemeke dan Longe, (2016), pelayanan akta kelahiran yang dilakukan secara online pada implementasi dari sistem pelayanan akta kelahiran secara mobile di Nigeria 
Virioner - Vol. $13 \backslash$ No. 2\ Agustus 2021 